
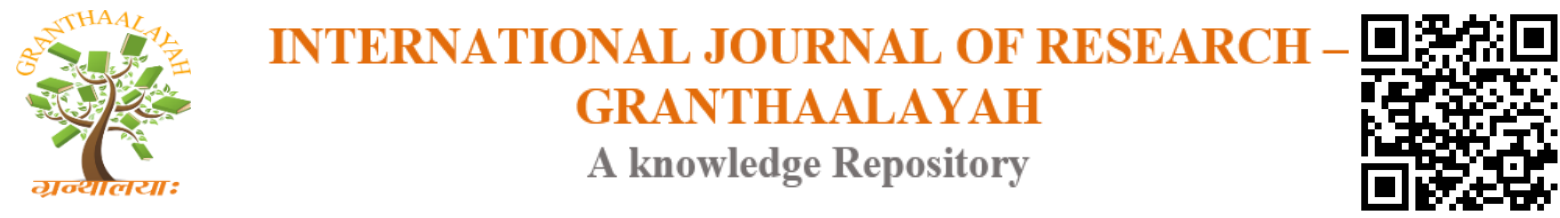

Management

\title{
SUPPORTING THE SUSTAINABILITY OF REGIONAL INDUSTRY CORE COMPETENCE IN SALATIGA
}

\author{
Sri Widiyati ${ }^{1}$, Edi Wijayanto ${ }^{2}$, Prihatiningsih ${ }^{3}$ \\ 1,2,3 Jurusan Akuntansi, Polines, Semarang, Indonesia
}

\begin{abstract}
A lot of small business activities become unbanked. The constraints faced related to knowledge limitations, limitations of information access and difficult requirements. The existence of branchless banking (BB) will help small business activities. They can easily to access formal financial institutions such as saving, payment, credit and insurance. The research aims to determine the regional industry core competence (RICC) in Salatiga, to find out the designing factors of BB and to choose the model of BB. The data used are secondary and primary data. Primary data obtained through interview and questionnaire from 200 small business activities. Scoring analysis based on OVOP criteria are used to determine RICC and to select branchless banking model used validity, reliability, factoring test and distribution of frequency. The study concluded that there are three superior products in Salatiga and one of them is processed food industry to be RICC and the corresponding BB model is the Bank Based Model.
\end{abstract}

Keywords: Unbanked; RICC; Processed Food Industry; Bank Based Model.

Cite This Article: Sri Widiyati, Edi Wijayanto, and Prihatiningsih. (2019). "SUPPORTING THE SUSTAINABILITY OF REGIONAL INDUSTRY CORE COMPETENCE IN SALATIGA." International Journal of Research - Granthaalayah, 7(6), 165-177. https://doi.org/10.29121/granthaalayah.v7.i6.2019.785.

\section{Introduction}

National development tries to increase economic growth rate and reduce disparities between regions. Each region competes in a healthy manner to gain a competitive advantage. At present the competitive advantage of an area is based on resources called core competency. With regard to regional autonomy, regional empowerment is carried out according to the potential that is owned and focused on the core business and strengthening local products.

According to Prahalad and Hamel (1994)1 core competency is an integrated set of capabilities from a series of resources and supporting devices that will push the success of competing. The characteristics possessed are as follows: (a) offering tangible benefits to customers; (b) it is very difficult for competitors to imitate and (c) provide access to various markets. While Khawasala, Hirindu (2017)2 mentions that there are three dimensions of core competence namely capabilities, 
competency and resources. Core competence is important for institution to gain a competitive advantage and then competitive advantage usually proceeds to grow an institution. Furthermore, Didem Enginoglu and Cenk Lacin Arikan (2016)3 explain that that core competence is becoming more crucial for competition in business environments. There are many attributes of core competencies as complexity, invisibility, inimitability, durability, appropriability, nonsubstitutability, and superiority. Moreover, Sabah Agha and Laith Alrubaiee (2012)4 emphasize that core competencies are valuable capabilities those are collective and unique. Those are the knowledge set that distinguishes an institution and provides a competitive advantage over others. From various meanings it can be concluded that core competency can be described as being appropriate unique, difficult to imitate, valuable, non-substitutability and superior in competition.

The Ministry of Industry's policies carry out regional industrial development through the establishment of Regional Industry Core Competencies abbreviated as RICC. Implementation of core competencies as the basis for regional development through the concept of One Village One Product (OVOP) developed by Governor Hiramatsu in Japan and in the form of SAKASAKTI (One District / City One Core Competence) as presented by Prof. Dr. Martani Huseini. The aim of this movement is to perfect local resources or products so that they can be accepted by the international market. The criteria of OVOP according to the Ministry of Industry are as follows (Direktorat Jenderal Industri Kecil dan Menengah : 2013)5 : (a) regional superior product; (b) unique, authentic, and distinctive in local culture; (c) good quality and attractive appearance ; (d) has a broad market, both domestic and international markets; (e) has high economic value and (f) can be a regional economy driver and produced consistently and continuously.

Salatiga is one of the industrial centers, but this sector has not been able to become an economic driver. The potential of micro, small, and medium enterprises is quite large, reaching 10,998 units spread across 4 sub-districts, 15,035 workers and having 14 superior products (Salatiga in Figures: 2016)6. Industrial development in Salatiga, leads to the development of RICC, so it is necessary to determine one of the superior products to become the RICC.

In general, Small Business sustainability constraints are financial and marketing factors. The sustainability of Small Business is often faced with financial constraints related to capital resources and also access to financial institutions. Businesspeople have limitations to save. This will make it difficult for them in the future if they need funds. On the other hand, credit schemes that are less suitable for micro and small businesses, administrative requirements that are complicated, burdensome interest rates make businesspeople often unable to maintain business continuity (Prihatiningsih et.all.: 20127; Sri Widiyati: 20148). Various reasons for business actors being unbanked both in terms of supply (service provider) and demand side (business actors), namely constraints on prices, information, product design, distribution facilities.

In line with the government program, namely the National Strategy of Inclusive Finance (Strategi Nasional Keuangan Inklusif -SNKI), the Financial Services Authority (OJK) issued the Financial Services Authority Regulation Number 19 / POJK.03 / 2014 concerning Officeless Financial Services in the Framework of Inclusive Finance. The name of the issue is Layanan Keuangan Tanpa Kantor dalam Rangka Keuangan Inklusif abbreviated as LAKU PANDAI or better known with Branchless Banking (BB). This program is a program for providing banking services and / or other financial services through collaboration with other parties (agents) and supported using 
information technology facilities. The aim of LAKU PANDAI is to provide financial products that are simple, easy to understand, and in accordance with the needs of unbanked communities who have not been able to reach financial services at this time.

In the application of Branchless Bank (BB) there are two commonly used models, namely bank based models and non-bank based models. In addition, there is a hybrid model which is a combination of bank based models with non-bank based models (Pungki Purnomo Wibowo: 2013)9. In bank based models, banks are creators of financial products and services but distribution is done through retail agents who manage all or almost all interactions with customers. The bank has the role of the initial licensing process, operational implementation, financial and system management. While the telko company has the role of providing a network / infrastructure channel to conduct banking service transactions. Telko companies get fees from network usage by customers. Types of service distribution channels are retail agents and mobile banking provided by banks. While the non-bank based model is mobile banking. which is the development of banking services. The Hybrid model is the organization of BB where there is cooperation between banks and non-bank institutions in the form of joint ventures and partnerships, to provide full banking services for customers via mobile phones. Services related to communication networks such as money transfer via SMS, charging electronic balances are the responsibility while the bank is responsible for mobile banking services such as deposit management, transfers between accounts and so on.

Research on branchless banks has been carried out. The research generally reveals the power of adoption (Ndumba Hannah Wangari and Muturi Willy, 201410; Pamela John Chogo and Eliamani, 201511; AA, Chaudry, A., Parveiz, Y. , Javed, 201612); studies on the impact of Branchless Banking on the performance of commercial banks show positive things (Gift Kimonge Dzombo; James M. Kilika \& James Maingi, 201713; Josiah Aduda, Patrick Kiragu and Jackline Murugi Ndwiga, 201314); study the impact of Branchless Banking on low income individual ( Sownya Hedge and Veena D.Kotian,2016 )15. The research that will be carried out is Branchless Banking model that accommodates the needs of Small Business. There are three forms of banks without offices, namely Model Based Bank, Non Bank Based Model and Hybrid ( Pungki Purnomo Wibowo, 2013).

Empowerment of Small Business can be done through the provision of affordable business financing sources. One financing strategy for this group is the micro credit business. Branchless Banking provides financial services that are specific in that they fulfill the demand for unbanked funds. Herefore, to maintain the sustainability of business people, strengthening capital resources and the ease of using banking services and other financial services is an immediate need. So that the research problem is "How is the form of Branchless Banking that is able to maintain the sustainability of the Salatiga RICC business unit”. In detail the problems raised in the study are described as follows: How to determine Salatiga RICC and how to determine and analyze the factors forming the design of the BB model.

\section{Materials and Methods}

Small Business in Salatiga was the target of population. A sampling approach was used for this study. The number of sample is 200 small businesses. The number of samples taken has met the 
requirements. According to Uma Sekaran (2006)16, the number of samples from 30 to 500 is appropriate for research. Sampling is done purposively sampling and sampling area. The sample criteria are small businesses who operate at least 3 years and each sub-district is taken by 50 respondents. (Salatiga consists of 4 sub-districts).

This study requires primary data and secondary data. Primary data collection is done by questionnaire, observation and interviews. Questionnaires are designed with open and closed statements and / or questions. To answers to closed questions are provided with 5 alternative answers with a Likert scale (scale 5 is very agree and answer 1 is strongly disagree). Observations are made to directly see and observe the conditions, activities and performance of business units. In-depth interviews are conducted face to face with the respondents. Documentation data is secondary data obtained from the Office of Cooperatives and MSMEs, data from BPS and other publications.

A three step analysis methods employed in this reseach to find RICC in Salatiga. First, identification analysis to select superior products. Second, rating analysis to select three highest rating as superior products. Third,from the three highest rating we choose RICC. Selection of superior products with OVOP criteria. Each criterion will be scored. Determination of scores for each of the following criteria: (a) Score 3 if the product has a big advantage from the relevant indicator; (b) Score 2 if the product has a moderate advantage from the relevant indicator; (c) Score 1 if the product has a low advantage from the relevant indicator.

To determine BB model, the research stages are as follow are : (a) Identify the forming factors of the Branchless Banking model design; (b) Test the validity and reliability of variable indicators . The variable indicator is said to be valid if the value of V.E is at least 0.5 . This means that the high variance extract value shows that the indicator used has represented a latent construct. Reliability test is related to the consistency of answers from respondents. Reliability levels that can be accepted if the value of Cronbach Alpa> 0.6. (Ghozali: 2006)17; (c) Factoring Analysis. Factoring analysis is essentially used to reduce data, namely the process of summarizing a number of variables into fewer and naming them as factors. The process of analyzing factors is as follows: 1) Selecting the appropriate variables for factor analysis. Between variables must be correlated and if the correlation is weak the variable is excluded from factor analysis. For this reason, MSA or Barlett's Test are used. 2) After that the variable extraction is carried out so that it becomes several variables. The popular search factor model is Pricipal Component and Maximum Likelihood. 3) If the contents of the factor are still in doubt, rotation is done so that the factors formed have been significantly different from other factors and 4) After the factors are formed, the next process is naming factors; (d) Choosing Model.

\section{Results and Discussion}

\subsection{Description of Salatiga City}

The economy of Salatiga is supported by small and medium industries. The existence of MSMIs is spread across sub-districts in Salatiga. Small and Medium Industries with an industrial center of a product found in several sub-districts even in one sub-district there are more than one industrial center. Statistics of Department of Industry, Trade, Cooperatives and MSME in 2015 shows the 
number of companies in Salatiga City as many as 1,942 units and spread across four Districts. Number of workers is 15,220 people while the number of small industries is 34,121 units with a workforce of 138,907 people. To determine the potential location of a particular product, the criteria used are the number of industries, labor, marketing areas, turnover and industrial scale. The performance of superior products of the District in the Salatiga region is as follow:

Table 1: Description of Industrial Performance

\begin{tabular}{|c|c|c|c|c|c|c|}
\hline \multicolumn{7}{|c|}{ Description of Industrial Performance } \\
\hline $\begin{array}{c}\text { District } \\
\text { Argomulyo }\end{array}$ & Product & $\begin{array}{c}\text { Number of } \\
\text { MSMEs }\end{array}$ & Labor & $\begin{array}{c}\text { Scale } \\
\text { Enterprises }\end{array}$ & Sector & $\begin{array}{c}\text { Superior } \\
\text { Product }\end{array}$ \\
\hline \multicolumn{7}{|l|}{ Sub District } \\
\hline Kumpul-rejo & $\begin{array}{l}\text { Dairy cows } \\
\text { Processed } \\
\text { Food }\end{array}$ & $\begin{array}{l}55 \\
2\end{array}$ & $\begin{array}{l}107 \\
2\end{array}$ & $\begin{array}{l}\text { Micro } \\
\text { Micro }\end{array}$ & $\begin{array}{l}\text { Agriculture } \\
\text { Manufacture }\end{array}$ & Dairy cows \\
\hline Randua-cir & $\begin{array}{l}\text { Dairy cows } \\
\text { Processed } \\
\text { Food }\end{array}$ & $\begin{array}{l}134 \\
9\end{array}$ & $\begin{array}{l}271 \\
17\end{array}$ & $\begin{array}{l}\text { Micro } \\
\text { Micro }\end{array}$ & $\begin{array}{l}\text { Agriculture } \\
\text { Manufacture }\end{array}$ & Dairy cows \\
\hline Ledok & $\begin{array}{l}\text { Processed } \\
\text { Food } \\
\text { Convection } \\
\text { Bamboo } \\
\text { Craft } \\
\end{array}$ & $\begin{array}{l}20 \\
3 \\
1\end{array}$ & $\begin{array}{l}58 \\
9 \\
8\end{array}$ & $\begin{array}{l}\text { Micro } \\
\text { Micro } \\
\text { Micro }\end{array}$ & $\begin{array}{l}\text { Manufacture } \\
\text { Manufacture } \\
\text { Manufacture }\end{array}$ & $\begin{array}{l}\text { Processed } \\
\text { Food }\end{array}$ \\
\hline Noborejo & $\begin{array}{l}\text { Processed } \\
\text { Food }\end{array}$ & 2 & 3 & Micro & Manufacture & $\begin{array}{l}\text { Processed } \\
\text { Food }\end{array}$ \\
\hline Tegalrejo & $\begin{array}{l}\text { Convection } \\
\text { Processed } \\
\text { Food }\end{array}$ & $\begin{array}{l}4 \\
23\end{array}$ & $\begin{array}{l}22 \\
60\end{array}$ & $\begin{array}{l}\text { Micro } \\
\text { Micro }\end{array}$ & $\begin{array}{l}\text { Manufacture } \\
\text { Manufacture }\end{array}$ & $\begin{array}{l}\text { Processed } \\
\text { Food }\end{array}$ \\
\hline Cebong-an & $\begin{array}{l}\text { Processed } \\
\text { Food }\end{array}$ & 7 & 32 & Micro & Manufacture & $\begin{array}{l}\text { Processed } \\
\text { Food }\end{array}$ \\
\hline Total & $\begin{array}{l}\text { Dairy cows } \\
\text { Processed } \\
\text { Food } \\
\text { Convection } \\
\text { Bamboo } \\
\text { Craft }\end{array}$ & $\begin{array}{l}189 \\
63 \\
7 \\
1\end{array}$ & $\begin{array}{l}378 \\
172 \\
31 \\
8\end{array}$ & $\begin{array}{l}\text { Micro } \\
\text { Micro } \\
\text { Micro } \\
\text { Micro }\end{array}$ & $\begin{array}{l}\text { Agriculture } \\
\text { Manufacture } \\
\text { Manufacture } \\
\text { Manufacture }\end{array}$ & Dairy cows \\
\hline \multicolumn{7}{|c|}{ Disrtict : Sidomukti } \\
\hline $\begin{array}{l}\text { Sub District : } \\
\text { Mangunsari }\end{array}$ & $\begin{array}{l}\text { Processed } \\
\text { Food } \\
\text { Convection }\end{array}$ & $\begin{array}{l}51 \\
6\end{array}$ & $\begin{array}{l}131 \\
27\end{array}$ & $\begin{array}{l}\text { Micro- } \\
\text { Kecil } \\
\text { Micro }\end{array}$ & $\begin{array}{l}\text { Manufacture } \\
\text { Manufacture }\end{array}$ & $\begin{array}{l}\text { Processed } \\
\text { Food }\end{array}$ \\
\hline Dukuh & $\begin{array}{l}\text { Processed } \\
\text { Food }\end{array}$ & 8 & 17 & Micro & Manufacture & $\begin{array}{l}\text { Processed } \\
\text { Food }\end{array}$ \\
\hline Kecandran & $\begin{array}{l}\text { Processed } \\
\text { Food } \\
\text { Convection }\end{array}$ & $\begin{array}{l}17 \\
3\end{array}$ & $\begin{array}{l}68 \\
5\end{array}$ & $\begin{array}{l}\text { Micro } \\
\text { Micro }\end{array}$ & $\begin{array}{l}\text { Manufacture } \\
\text { Manufacture }\end{array}$ & $\begin{array}{l}\text { Processed } \\
\text { Food }\end{array}$ \\
\hline Kalicacing & $\begin{array}{l}\text { Processed } \\
\text { Food }\end{array}$ & $\begin{array}{l}29 \\
3\end{array}$ & $\begin{array}{l}60 \\
5\end{array}$ & $\begin{array}{l}\text { Micro } \\
\text { Micro }\end{array}$ & $\begin{array}{l}\text { Manufacture } \\
\text { Manufacture }\end{array}$ & $\begin{array}{l}\text { Processed } \\
\text { Food }\end{array}$ \\
\hline
\end{tabular}


DOI: 10.5281/zenodo.3266253

\begin{tabular}{|c|c|c|c|c|c|c|}
\hline & Convection & & & & & \\
\hline Total & $\begin{array}{l}\text { Processed } \\
\text { Food } \\
\text { Convection }\end{array}$ & $\begin{array}{l}105 \\
12\end{array}$ & $\begin{array}{l}276 \\
42\end{array}$ & $\begin{array}{l}\text { Micro- } \\
\text { Small } \\
\text { Micro }\end{array}$ & $\begin{array}{l}\text { Manufacture } \\
\text { Manufacture }\end{array}$ & $\begin{array}{l}\text { Processed } \\
\text { Food }\end{array}$ \\
\hline \multicolumn{7}{|c|}{ District: Sidorejo } \\
\hline $\begin{array}{l}\text { Sub District: } \\
\text { Salatiga }\end{array}$ & $\begin{array}{l}\text { Processed } \\
\text { Food } \\
\text { Convection } \\
\text { Bamboo } \\
\text { Craft } \\
\end{array}$ & $\begin{array}{l}25 \\
4 \\
1\end{array}$ & $\begin{array}{l}140 \\
38 \\
10\end{array}$ & $\begin{array}{l}\text { Micro } \\
\text { Micro } \\
\text { Micro }\end{array}$ & $\begin{array}{l}\text { Manufacture } \\
\text { Manufacture } \\
\text { Manufacture }\end{array}$ & $\begin{array}{l}\text { Processed } \\
\text { Food }\end{array}$ \\
\hline \multirow[t]{2}{*}{$\begin{array}{l}\text { Sub District: } \\
\text { Pulutan }\end{array}$} & $\begin{array}{l}\text { Processed } \\
\text { Food }\end{array}$ & 1 & 2 & Micro & Manufacture & $\begin{array}{l}\text { Processed } \\
\text { Food }\end{array}$ \\
\hline & $\begin{array}{l}\text { Processed } \\
\text { Food }\end{array}$ & 2 & 16 & $\begin{array}{l}\text { Micro- } \\
\text { Small } \\
\end{array}$ & Manufacture & $\begin{array}{l}\text { Processed } \\
\text { Food }\end{array}$ \\
\hline Blotongan & $\begin{array}{l}\text { Processed } \\
\text { Food }\end{array}$ & 22 & 53 & $\begin{array}{l}\text { Micro- } \\
\text { Small } \\
\end{array}$ & Manufacture & $\begin{array}{l}\text { Processed } \\
\text { Food }\end{array}$ \\
\hline Kauman Kidul & $\begin{array}{l}\text { Processed } \\
\text { Food } \\
\text { Convection }\end{array}$ & $\begin{array}{l}2 \\
2\end{array}$ & $\begin{array}{l}6 \\
5\end{array}$ & $\begin{array}{l}\text { Micro } \\
\text { Micro }\end{array}$ & $\begin{array}{l}\text { Manufacture } \\
\text { Manufacture }\end{array}$ & $\begin{array}{l}\text { Processed } \\
\text { Food }\end{array}$ \\
\hline Sidorejo & $\begin{array}{l}\text { Convection } \\
\text { Processed } \\
\text { Food } \\
\text { Bamboo } \\
\text { Craft }\end{array}$ & $\begin{array}{l}39 \\
77 \\
1\end{array}$ & $\begin{array}{l}365 \\
331 \\
10\end{array}$ & $\begin{array}{l}\text { Micro- } \\
\text { Small } \\
\text { Micro- } \\
\text { Small } \\
\text { Micro }\end{array}$ & $\begin{array}{l}\text { Manufacture } \\
\text { Manufacture } \\
\text { Manufacture }\end{array}$ & $\begin{array}{l}\text { Processed } \\
\text { Food }\end{array}$ \\
\hline \multicolumn{7}{|c|}{ District: Tingkir } \\
\hline $\begin{array}{l}\text { Sub District: } \\
\text { Tingkir Lor }\end{array}$ & $\begin{array}{l}\text { Convection } \\
\text { Processed } \\
\text { Food }\end{array}$ & $\begin{array}{l}33 \\
12\end{array}$ & $\begin{array}{l}106 \\
66\end{array}$ & $\begin{array}{l}\text { Micro- } \\
\text { Small } \\
\text { Micro }\end{array}$ & $\begin{array}{l}\text { Manufacture } \\
\text { Manufacture }\end{array}$ & Convection \\
\hline $\begin{array}{l}\text { Tingkir } \\
\text { Tengah }\end{array}$ & $\begin{array}{l}\text { Convection } \\
\text { Processed } \\
\text { Food }\end{array}$ & $\begin{array}{l}10 \\
17\end{array}$ & $\begin{array}{l}114 \\
54\end{array}$ & $\begin{array}{l}\text { Micro- } \\
\text { Small } \\
\text { Micro }\end{array}$ & $\begin{array}{l}\text { Manufacture } \\
\text { Manufacture }\end{array}$ & Convection \\
\hline Kalibening & $\begin{array}{l}\text { Convection } \\
\text { Processed } \\
\text { Food }\end{array}$ & $\begin{array}{l}2 \\
5\end{array}$ & $\begin{array}{l}23 \\
36\end{array}$ & $\begin{array}{l}\text { Micro- } \\
\text { Small } \\
\text { Micro }\end{array}$ & $\begin{array}{l}\text { Manufacture } \\
\text { Manufacture }\end{array}$ & $\begin{array}{l}\text { Processed } \\
\text { Food }\end{array}$ \\
\hline $\begin{array}{l}\text { Kelurahan } \\
\text { Kutowinangun }\end{array}$ & $\begin{array}{l}\text { Convection } \\
\text { Processed } \\
\text { Food }\end{array}$ & $\begin{array}{l}2 \\
13\end{array}$ & $\begin{array}{l}13 \\
108\end{array}$ & $\begin{array}{l}\text { Micro } \\
\text { Micro- } \\
\text { Small }\end{array}$ & $\begin{array}{l}\text { Manufacture } \\
\text { Manufacture } \\
\text { Pengolahan } \\
\text { Pengolahan }\end{array}$ & $\begin{array}{l}\text { Processed } \\
\text { Food }\end{array}$ \\
\hline Gendongan & $\begin{array}{l}\text { Convection } \\
\text { Processed } \\
\text { Food }\end{array}$ & $\begin{array}{l}3 \\
6\end{array}$ & $\begin{array}{l}50 \\
21\end{array}$ & $\begin{array}{l}\text { Micro } \\
\text { Micro- } \\
\text { Small }\end{array}$ & $\begin{array}{l}\text { Manufacture } \\
\text { Manufacture }\end{array}$ & Convection \\
\hline Total & $\begin{array}{l}\text { Convection } \\
\text { Processed } \\
\text { Food }\end{array}$ & $\begin{array}{l}48 \\
53\end{array}$ & $\begin{array}{l}306 \\
287\end{array}$ & $\begin{array}{l}\text { Micro- } \\
\text { Small } \\
\text { Micro- } \\
\text { Small }\end{array}$ & $\begin{array}{l}\text { Manufacture } \\
\text { Manufacture }\end{array}$ & Convection \\
\hline
\end{tabular}

Source: Data Processing Results 2018 


\subsection{Determination of RICC}

From table 1, it can be seen that Salatiga has three superior products, namely dairy cows, convection and processed food. Among the three types of superior products will be selected one to become RICC. The criteria used are based on OVOP criteria. a) a regional superior product; (b) unique, authentic, and distinctive in local culture; (c) good quality and attractive apperance ; (d) has a broad market, both domestic and international markets; (e) has high economic value and (f) can be a regional economy driver and produced consistently and continuously by using scores. The scoring results are shown in table 2

Table 2: Superior Product in Salatiga

\begin{tabular}{|l|l|l|l|l|l|l|l|}
\hline Superior Product & \multicolumn{7}{|c|}{ Criteria } \\
\hline & a & b & c & d & e & f & Total \\
\hline Processed Food & 3 & 3 & 2 & 2 & 2 & 3 & 15 \\
\hline Convection & 1 & 1 & 2 & 2 & 2 & 3 & 11 \\
\hline Dairy cows & 1 & 2 & 1 & 2 & 2 & 2 & 10 \\
\hline
\end{tabular}

Source: Data Processing Results 2018

From the results of the rating above, processed food is the regional industry core competence. Processed food has its own uniqueness and is currently diversified. In addition, there are peanuts and pulmonary chips. In accordance with the potential of the local area, there are also famous foods. This food recorded traces of Chinese citizens in Salatiga, namely enting-enting gepuk. Other processed foods that are well known are getuk ketek, the food from cassava is innovated to become cassava cheese.

\subsection{Determination of Branchless Banking Model}

The first step is to test the validity and reliability of 15 statements which are BB determinants. The 15 statement items are as follows: X1: Products vary; X2: The location of financial institutions is easy to reach; X3: Administrative costs are affordable; X4: The requirement to open an account is easy; X5: Friendly clerk; X6: Flexible working hours;X7: The clerk is easy questioned; X8: Adequate facilities; X9: Close to home; X10: Access to financial institution locations is easy; X12: Deposit Guarantee Institution; X13: Public transportation mobility; X14: Taking deposits is easy and X15: Low initial deposit. Testing the validity by using product moment correlation. The results of testing validity are seen in the table below:

Table 3: Validity Test Results

\begin{tabular}{|c|c|c|c|c|c|}
\hline Indicator & Sig & Criteria & Indicator & Sig & Criteria \\
\hline X1 & $\mathbf{0 , 0 0 0}$ & Valid & X9 & 0,000 & Valid \\
\hline X2 & 0,000 & Valid & X10 & 0,000 & Valid \\
\hline X3 & 0,000 & Valid & X11 & 0,429 & Tidak Valid \\
\hline X4 & 0,000 & Valid & X12 & 0,000 & Valid \\
\hline X5 & 0,000 & Valid & X13 & 0,000 & Valid \\
\hline X6 & 0,000 & Valid & X14 & 0,000 & Valid \\
\hline X7 & 0,000 & Valid & X15 & 0,000 & Valid \\
\hline X8 & 0,000 & Valid & & & \\
\hline
\end{tabular}

Source: Data Processing Results: 2018 
From the table above, it appears that most all indicators with a level of $\alpha<0.05$ so that the indicator is declared valid. Because it is valid, it can be processed for further analysts except X11.

\subsection{Reliability Analysis}

Reliability test is conducted to determine the consistency and indicator used to measure is the Croncbach alpha coefficient. Cronbach alpha is $0.661 ; 0.654 ; 0.662$ and 0.709 . Based on the indicator, if cronbach alpha is greater than 0.60 , then the measuring instrument can be trusted. The results show that the croncbach value $>0.60$ is reliable. The full results are shown in the table 4 .

Table 4: Reliability Test

\begin{tabular}{|c|c|c|c|}
\hline Variabel & Cronbach's Alpha & Parameter Alpha & Kriteria \\
\hline $\mathrm{X} 111$ & 0.661 & 0,6 & Reliabel \\
\hline $\mathrm{X} 222$ & 0.654 & 0,6 & Reliabel \\
\hline $\mathrm{X} 333$ & 0.662 & 0,6 & Reliabel \\
\hline X444 & 0.709 & 0,6 & Reliabel \\
\hline
\end{tabular}

Source: Data Processing Results 2018

\subsection{Factoring Analysis}

The data matrix must have sufficient correlation which is a condition for factor analysis. Testing the correlation between variabe using Bartlett test of sphericity. If the test results are significant then there is correlation between variables in the matrix. Measure of sampling adequacy (MSA) used to see intercorrelations between variables and whether or not factor analysis is done. If MSA $<0.5$ factor analysis cannot be done. (Imam Ghozali: 2006).

Factor analysis is done to simplify the complex relationship between a number of observation variables by forming a shared dimension or factor. In this study, factor analysis is aimed at simplifying the variable of BB model consisting of 15 statements into several factors. The simplification of this variable can be used to design BB model.

KMO and Bartlett's Test

\begin{tabular}{|c|c|c|}
\hline \multicolumn{2}{|c|}{ Kaiser-Meyer-Olkin Measure of Sampling Adequacy. } & .512 \\
\hline \multirow{3}{*}{$\begin{array}{l}\text { Bartlett's Test of } \\
\text { Sphericity }\end{array}$} & Approx. Chi-Square & 207.564 \\
\hline & df & 78 \\
\hline & Sig. & .000 \\
\hline
\end{tabular}

In the table above, KMO and Bartlett's test, the numbers K-M-O are seen, Measure of Sampling Adequacy (MSA) is 0.512. Because the number of MSA is above 0.5, the collection of variants can be further processed. Then each variable is analyzed to find out which ones can be processed further and which ones must be excluded. 
Table 5: Anti-image Matrices

\begin{tabular}{|c|c|c|c|}
\hline Indikator & MSA & Indikator & MSA \\
\hline X1 & 0.308 & X8 & 0.455 \\
\hline X2 & 0.488 & X9 & 0.528 \\
\hline X3 & 0.506 & X10 & 0.495 \\
\hline X4 & 0.457 & X12 & 0.500 \\
\hline X5 & 0.489 & X13 & 0.522 \\
\hline X6 & 0.497 & X14 & 0.587 \\
\hline X7 & 0.470 & X15 & 0.461 \\
\hline
\end{tabular}

Source: Data Processing Results 2018

At Anti Image Correlation, there are all indicators with MSA values above 0.5 except X1. This indicates that the indicator can be processed further. The next test shows that KMO-MSA is 0.514, so that the collection of variants can be further processed. The next step analyzes each variable whether the variable is issued or processed further.

KMO and Bartlett's Test

\begin{tabular}{|ll|r|}
\hline Kaiser-Meyer-Olkin Measure of Sampling Adequacy. & .514 \\
Bartlett's Test of & Approx. Chi-Square & 207.627 \\
Sphericity & df & 78 \\
& Sig. & .000 \\
\hline
\end{tabular}

Anti-image Matrices

\begin{tabular}{|c|c|c|c|}
\hline Indikator & MSA & Indikator & MSA \\
\hline X2 & 0.534 & X8 & 0.457 \\
\hline X3 & 0.510 & X9 & 0.537 \\
\hline X4 & 0.472 & X10 & 0.516 \\
\hline X5 & 0.501 & X12 & 0.499 \\
\hline X6 & 0.504 & X13 & 0.525 \\
\hline X7 & 0.503 & X14 & 0.594 \\
\hline & & X15 & 0.512 \\
\hline
\end{tabular}

In the Anti Image Correlation table, there are all indicators with MSA values above 0.5 except X1. For X4 and X8 the value of MSA is rounded to $>0.500$. This indicates that the indicator can be processed further. 
Total Variance Explained

\begin{tabular}{|l|c|r|r|r|r|r|}
\hline \multirow{2}{*}{ Component } & \multicolumn{3}{|c|}{ Initial Eigenvalues } & \multicolumn{3}{|c|}{ Extraction Sums of Squared Loadings } \\
\cline { 2 - 7 } & Total & \% of Variance & Cumulative \% & Total & \% of Variance & Cumulative \% \\
\hline 1 & 1.778 & 14.814 & 14.814 & 1.778 & 14.814 & 14.814 \\
2 & 1.716 & 14.297 & 29.111 & 1.716 & 14.297 & 29.111 \\
3 & 1.362 & 11.354 & 40.465 & 1.362 & 11.354 & 40.465 \\
4 & 1.236 & 10.301 & 50.766 & 1.236 & 10.301 & 50.766 \\
5 & 1.225 & 10.212 & 60.978 & 1.225 & 10.212 & 60.978 \\
6 & .962 & 8.014 & 68.992 & & & \\
7 & .848 & 7.066 & 76.059 & & & \\
8 & .779 & 6.489 & 82.548 & & & \\
9 & .677 & 5.643 & 88.190 & & & \\
10 & .527 & 4.395 & 92.586 & & & \\
11 & .466 & 3.881 & 96.467 & & & \\
12 & .424 & 3.533 & 100.000 & & & \\
\hline
\end{tabular}

Extraction Method: Principal Component Analysis.

\section{Component Matrix ${ }^{a}$}

\begin{tabular}{|l|c|r|r|r|l|}
\hline & \multicolumn{5}{|c|}{ Component } \\
\cline { 2 - 6 } & 1 & 2 & 3 & 4 & \multicolumn{1}{l|}{5} \\
\hline X2 & .483 & .321 & .471 & .273 & -.187 \\
X3 & -.244 & -.258 & .326 & -.069 & -.325 \\
X4 & .162 & -.161 & .434 & -.423 & .420 \\
X5 & .284 & -.645 & .440 & .099 & .155 \\
X6 & -.027 & .572 & -.181 & .163 & .466 \\
X7 & .160 & -.568 & .062 & .372 & .412 \\
X8 & -.064 & .298 & .478 & -.585 & -.206 \\
X9 & .614 & .298 & .059 & .212 & -.017 \\
X10 & .801 & .142 & -.072 & -.030 & -.112 \\
X12 & -.215 & -.182 & .072 & .467 & -.532 \\
X13 & -.443 & .220 & .306 & .205 & .397 \\
X15 & -.292 & .418 & .529 & .394 & .022 \\
\hline
\end{tabular}

Extraction Method: Principal Component Analysis.

a. 5 components extracted.

Based on the Component Matrix table, there are 5 Components, meaning there are 5 factors formed. This is supported by a table of total variance explained where with five factors, the number of eigenvalues above 1. From the 13 empirical indicators analyzed, the results of computer extraction turned out to be five factors (eigen value> 1 becomes a factor). The first factor is able to explain $14.814 \%$ variation and factor 2 able to explain $14.297 \%$ variation, factor 3 is able to explain $11.354 \%$ variation; factor four and factor five can explain 10,301 and 10,212 variations. 
So, all five factors can explain $60.978 \%$ of the variation. Factor one includes X2; X9; X10; X13. The grouping in factor two is: $\mathrm{X} 5$; $\mathrm{X} 6$; $\mathrm{X} 7$. The grouping in factor three is: $\mathrm{X} 3$; $\mathrm{X} 4$; $\mathrm{X} 15$. Grouping in factor four is X8 and grouping in factor 5 is X12. Naming factors are as follows: Factor 1: Location; Factor 2: Service; Factor 3: Account Opening; Factor 4: Facilities. and Factor 5: Deposit Guarantee Institution.

\subsection{The Desire of Small Businesses to Branchless Banking Model}

In essence, financial services are already the needs of society in general. One of the most significant initiatives taken by OJK is Financial Literacy and Financial Inclusion. Financial Literacy and Financial Inclusion are two related matters. Banks in Indonesia embrace financial inclusion by innovation in service delivery process and information technology. Banks in Indonesia also improve customers acceptance in using bank innovation. Financial Services without Branch Offices in the Context of Inclusive Finance is one way of access to financial services.

The survey results showed that more than $90 \%$ of respondents had been and were still customers of financial institutions. The average respondent becomes a Cooperative, Pawnshop and Banking customer. Products consumed are generally savings, credit and transfers as well as other payment point services.

Based on factoring analysis, that are five factors are considered by customers to choose BB model. The factors are location, service. Account opening, facilities and deposit guarantee institution. The study showed that $87 \%$ respondents wanted Lembaga Penjamin Simpanan (Deposit Guarantee Institution). The feel safe about their savings even though the bank faces up financial problem. The Deposit Guarantee Institution has responsibility to bank customers. The second consideration is service. $83 \%$ respondents want friendly staff, and they want the staff will give a clear explanation when the customers need. Another service that the customers want is the flexibility of financial institution working hours. They expect to visit financial institution at any time because the working hour of small business are uncertain. Another thing that they consider is the cost. They hope the cost of opening an account and other cost of transaction are cheaper than others. The fourth consideration is location. Nearly $70 \%$ respondents want that the location is near from their house or their work place so that they can save transportation cost. Most of the respondents don't think about services like parking area, AC, waiting room and only $32 \%$ respondents choose this factor.

There are three forms of branchless banks namely Bank Based Model, Non Bank Based Model and a combination of both called hybrid models. Based on the results of factoring analysis, respondents' preference for the form of a branchless bank is Bank Based Model. Agents who have fulfilled the requirements become an extension of the bank. The presence of an agent will reduce the proximity barriers, high cost barriers, information barriers and barriers associated with documentation requirements. It can facilitate the delivery of financial services. The agents provide small businesses the ability to make deposit and withdrawals without going to actual bank. Small Businesses are able to use actively a financial product that it has to be suitable for them in terms in cost, time restrictions and so on. 


\section{Conclusions and Recommendations}

\subsection{Conclusions}

The results of the study show that there are three products that can be seeded in Salatiga. The three products are convection, processed food, and dairy cows. One of them will be the Salatiga Regional Core Industry Competence. (RICC) .By using the OVOP criteria (one village one product), so processed food become the Regional Core Competencies in Salatiga.

Based on the factoring analysis results associated with bank preferences without branchless there are five things that are considered, namely: location; service; ease of account opening; the facilities provided and the guarantee of customer deposits. There are three forms of branchless banks namely Bank Based Model, Non Bank Based Model and a combination both of them called hybrid models. Based on the results of factoring analysis, respondents' preference for the form of a branchless bank is Bank Based Model. The integration between non traditional channels and formal finance with micro finance approach will fulfill the need of small businesses.

\subsection{Recommendations}

From the study findings and the conclusions, the study recommends first, the existence of a branchless bank needs to be increased, especially in rural areas that are the center of small industries. Secondly, banks and branchless bank agents need to socialize that transactions at branchless banks are safe. Third, the core competencies of regional industries need government assistance so that they have strong competitiveness.

\section{Acknowledgements}

We would like to acknowledge to Ristek Dikti for the assistance of research funds. We would like to thank the Accounting Department and Chairman for the facilities and equipments, we need to produce and complete the research report. Last but not least we would like to thank to our respondents who have giving data and informations.

\section{References}

[1] Prahalad, C.K. and Hamel, G. The Core Competence of the Coorporation. Harvard Business Review 68 (3), 1994,79-91.

[2] Kawshala, Hirindu. Theorizing the Concept of Core Competencies: An Integrative Model beyond Identification. International Journal of Scientific and Research Publications, Volume 7, Issue 2, February,2017.

[3] Arikan,Cenk Lacin, Enginoglu,Didem .A Literature Review on Core Competencies.International Journal of management (IJM).Volume 7,Issue 3,March-April, 2016, page 120-127.

[4] Alrubaiee, Laith, Agha, Sabah. Effect of Core Competence on Competitive Advantage and Organizational Performance. International Journal of Business and Management.,Vol.7 No.1,January,2012.

[5] Direktorat Jenderal Industri Kecil Dan Menengah Kementerian Perindustrian. Buku Petunjuk Teknis. Penilaian, Klasifikasi, Dan Pembinaan Produk OVOP. Jakarta, 2012.

[6] BPS, Salatiga in Figures: 2016. 
[7] Prihatiningsih, Sri Widiyati,Moh.Rois.2012.Model Penguatan Kapasitas Kerajinan Logam dan Suku Cadang Mesin Untuk Meningkatkan PAD Kabupaten Tegal. Unpblished.

[8] Widiyati,Sri. Peningkatan Kapasitas Produk Unggulan Batik Bakaran. Jurnal Keuangan dan Bisnis. Vol.3 no. 1 tahun III bulan April,2014.

[9] Wibowo,Pungky Purnomo. Branchless Banking setelah Multilicense :Ancaman atau Kesempatan bagi Perbankan Nasional. Jakarta 27 Juni 2013.

[10] Ndumba,Hannah Wangari dan Muturi Wiily. Factors Affecting Adoption of Mobile Banking in Kenya: Case Studiy of Kenya Commercial Bank Limuru. International Journal of Social Sciences Management and Enterpreneurship 1(3): 92-112, November,2014.

[11] Chongo,Pamela John dan Sedoyeka Eliamani. Exploring Factors Affecting Mobile Money Adoption in Tanzania. International Journal of Computing and ICT research, Vo.8,2015.

[12] A.A.,Chaudhry, A.,Parveiz, Y.,Javed. Determinants of Users Trust for Branchless Banking in Pakistan. Journal of Internet Banking and Commerce. April 2016, vol. 21, no. 1,2016.

[13] Maingi,James, Kilika,James M.,Dzombo,Gift Kimonge. The Effect of Branchless Banking Strategy on Financial Performance of Commercial Banks in Kenya. International Journal of Financial Research, Vol.8, No.4,2017.

[14] Ndwiga,Jackine Murugi, Kiragu, Patrick and Aduda,Josiah.The Relationship between Agency Banking and Financial Performance of Commercial Bank in Kenya. Journal of Finance and Investment Analysis, Vol2, No.4,2013.

[15] Kotian,Veena D, Hedge, Sowmya. Branchless Banking for The Poor as a Part of Financial Inclusion. International Journal of Scientific Research and Modern Education, Vo.1, Issue II,2016.

[16] Sekaran,Uma. Metodologi Penelitian Untuk Bisnis.Salemba Empat.Jakarta,2006.

[17] Ghozali,Imam.Analisis Multivariate Lanjutan Dengan Program SPSS. Badan Penerbit Universitas Diponegoro.Semarang,2006.

\footnotetext{
*Corresponding author.

E-mail address: wiwidsoemodipoero@yahoo.co.id
} 